\title{
Mind Mapping on Development of Human Resource of Education
}

\author{
Anis Fauzi (Corresponding author) \\ State Islamic Institute of Sultan Maulana Hasanuddin Banten \\ Sudirman Street No. 30, Serang City, Banten Province, Indonesia \\ E-mail: Jantera_Anis@yahoo.com
}

Received: October 25, 2016 Accepted: December 19, 2016

Published: December 23, 2016

doi:10.5296/jei.v2i2.10222 URL: http://dx.doi.org/10.5296/jei.v2i2.10222

\begin{abstract}
Human resources in the field of education consists of students, teachers, administrative staff, university students, lecturers, structural employees, educational bureaucrats, stakeholders, parents, the society around the school, and the society around the campus. The existence of human resources need to be cultivated and developed towards the better of the situation that exists today. Which elements of human resources in education are preferred to be fostered and developed further depends on the designer's idea of development in the field of education. The development of human resources on education should include all elements. Elements of the students and the university students need to be developed simultaneously, the element of administrative staff and employees need to be developed optimally, elements of teachers and lecturers need to be developed professionally, elements of the stakeholders, the community around schools and colleges need to be developed further to be more productive, more innovative, and more creative. Of course by emphasizing on performance, motivation, reward, and certain punishment.
\end{abstract}

Keywords: Idea, Development, Human Resources, Education

\section{Introduction}

Human resources of education consists of students, teachers, administrative staff, students, faculty, structural staff, educational bureaucrats, stakeholders, parents of students, the community around the school, and the community around the campus. Human resources of education has its own character, the special patterns of interaction, often conflicting, it may be an effort to integrate, and there are opportunities to collaborate in order to empower the fellow of human resource education. 
The existence of human resources needs to be fostered and developed to be better. Human resources element in education is preferred to be fostered and developed further dependent on the idea of development planners of education. It should not give priority to one element of human resources in education, but ignore the other elements of the human resources of education. It may be, in certain areas and at certain times, teachers play a key role in development on human resource of education. But that situation will change if we studying the problems of human resources of education that urged at other regions in the same time, let's say there are areas that prioritizes the construction of school buildings permanently than the supply of new teachers. In other areas it is more concerned to get and increase the number of students at all levels and types of education rather than fostering the performance of teachers and complete the infrastructure.

The development of human resource on education should include all the elements. Elements students and students need to be developed simultaneously, the element of administrative staff and employees need to be developed optimally, elements of teachers and lecturers need to be developed in a professionally, elements of the stakeholders, the community around the school and college need further developed. Of course by emphasizing on performance, motivation, reward and punishment.

According to Dedy Mulyasana (2011, p. 16), educational resources have not been sufficient to support the achievement of goals and educational targets effectively. Educational Resource is still perceived as weak in achieving national education goals. The existing educational resources more focused on administrative matters rather than directed to the learning process as a whole, total and thorough.

In the other parts, Dedy Mulyasana (2011, p. 23) stated that the demand of changes have forced educational paradigm slowly to be better, professional and democratic. The impact is, it will be a change in the paradigm of education.

The management and implementation of national education in Indonesia it is time to apply the paradigm of educational management as elements of the development strategy for education, it was based on the following considerations (Onisimus Amru, 2011, pp. 27-28): First, management is not only related to the product in the form of goods (material) but also in the form of services. Second, the quality of educational products takes place in a process and activity that requires participations and responsibilities of all elements (government, education providers, communities and stakeholders). Third, management of education can be viewed as a strategy to improve the quality, relevance and competitiveness of education, which has humanity base and requires empowerment through learning activities. Fourth, educational organizations can adopt the management structure of education. Attitude, cultural and educational organizations working climate in a long period has implicated for the bureaucrats and practitioners.

The problem is how to putting the target of coaching and developing human resources that work in the area of education. It certainly required thinking strategies and specific policy that more transparant and focused. 
Based on the background above, the main problems in this study is: How do the characteristics of developing a human resources in the field of education, interaction patterns between human resources of education, tips on facing horizontal conflicts among human resources in education, build the spirit of integration between human resources in education, and development patterns collaboration between HR education?

The purpose of this study as follows: First, understand the characteristics of developing human resources in the field of education. Second, understand the patterns of interaction between human resources in educations. Third, understand the tips on facing the horizontal conflicts among human resources in education. Fourth, understand the spirit of integration between human resources in educations. Fifth, understand the development patterns of collaboration between human resources in educations.

\section{Literature Review}

According to Gudmund Hernes in Nanang Fatah (2012), there are seven global challenges faced by the education sector, these are: (1) reduce the gap in the distribution of education, poverty, marginalization and exclusivity of education, (2) establish a better relationship between education and the local economy and education with the globalized work area, (3) Prevent the growing role of research and education that are controlled by the market and widening the gap of technology and knowledge between industrialized countries and developing countries, (4) Ensure that the requirements of research on developing countries get attention and from scientists and graduate, (5) Reducing the negative impact of "brain drain" from poor to rich country, and from poor to be better, (6) directs the impact of marketing principles and the changing role of the state to education, and (7) Using the educational system is not only to move the science in general.

According Tilaar (2000), decentralization of education would strengthen the growth of better nationality and more real because it is based on the wealth of local cultural or practice of local education. Decentralization of education is a complex process, because: (1) it will create an educational system with concrete policies; (2) regulate the resource and its utilization; (3) train the professional personnel (HR), both teachers and managers at the field level; (4) develop appropriate curriculum, and (5) managing the education system based on the local culture.

Research result of Monty FNGR (Research Journal of Education Policy, 2014) about Study Programme Implementation of Secondary Education Universal at SMA and SMK on Balangan South Kalimantan, it concluded that the biggest challenges faced by principals are still many teachers who are less dedicated to the development of school, this may have an impact on the implementation of the Universal Secondary Education program later, because the teacher is expected to be spearhead of the implementation of the program. At next part, Monty FNGR concluded that local governments should cooperate with third parties in terms of providing assistance to students who do not receive school operational assistance.

\section{Results and Discussion}

To explore the possibility of suppression target of human resource development, the authors 
will make the concept of "Mind mapping of Human Resource Development of Education", as shown in the following matrix.

Table 1. Matrix HR development thinking education

\begin{tabular}{|c|c|c|c|c|}
\hline Characteristic & Interaction & Conflict & Integration & Collaboration \\
\hline Teacher & $\begin{array}{l}\text { Teacher and } \\
\text { lecturer }\end{array}$ & $\begin{array}{l}\text { Teacher and } \\
\text { lecturer }\end{array}$ & $\begin{array}{l}\text { Teacher and } \\
\text { lecturer }\end{array}$ & $\begin{array}{l}\text { Teacher and } \\
\text { lecturer }\end{array}$ \\
\hline Lecturer & $\begin{array}{l}\text { Teacher and } \\
\text { students }\end{array}$ & $\begin{array}{l}\text { Teacher and } \\
\text { students }\end{array}$ & $\begin{array}{l}\text { Teacher and } \\
\text { students }\end{array}$ & $\begin{array}{l}\text { Teacher and } \\
\text { students }\end{array}$ \\
\hline Student & $\begin{array}{l}\text { Teacher and } \\
\text { student of college }\end{array}$ & $\begin{array}{l}\text { Teacher and } \\
\text { student of college }\end{array}$ & $\begin{array}{l}\text { Teacher and } \\
\text { student of college }\end{array}$ & $\begin{array}{l}\text { Teacher and } \\
\text { student of college }\end{array}$ \\
\hline Students of college & Teacher and staff & Teacher and staff & Teacher and staff & Teacher and staff \\
\hline Administration & $\begin{array}{l}\text { Lecturer and } \\
\text { student }\end{array}$ & $\begin{array}{l}\text { Lecturer and } \\
\text { student }\end{array}$ & $\begin{array}{l}\text { Lecturer and } \\
\text { student }\end{array}$ & $\begin{array}{l}\text { Lecturer and } \\
\text { student }\end{array}$ \\
\hline Stakeholder & $\begin{array}{l}\text { Lecturer and } \\
\text { student of college }\end{array}$ & $\begin{array}{l}\text { Lecturer and } \\
\text { student of college }\end{array}$ & $\begin{array}{l}\text { Lecturer and } \\
\text { student of college }\end{array}$ & $\begin{array}{l}\text { Lecturer and } \\
\text { student of college }\end{array}$ \\
\hline Parents of student & Lecturer and staff & Lecturer and staff & Lecturer and staff & Lecturer and staff \\
\hline $\begin{array}{l}\text { Parents of student of } \\
\text { college }\end{array}$ & $\begin{array}{l}\text { Student and } \\
\text { student of college }\end{array}$ & $\begin{array}{l}\text { Student and } \\
\text { student of college }\end{array}$ & $\begin{array}{l}\text { Student and } \\
\text { student of college }\end{array}$ & $\begin{array}{l}\text { Student and } \\
\text { student of college }\end{array}$ \\
\hline Society around school & Student and staff & Student and staff & Student and staff & Student and staff \\
\hline Society around university & $\begin{array}{l}\text { Student of } \\
\text { college and staff }\end{array}$ & $\begin{array}{l}\text { Student of } \\
\text { college and staff }\end{array}$ & $\begin{array}{l}\text { Student of } \\
\text { college and staff }\end{array}$ & $\begin{array}{l}\text { Student of } \\
\text { college and staff }\end{array}$ \\
\hline
\end{tabular}

\subsection{Characteristics of Human Resource of Education}

Human Resources of Education consists of: teachers, lecturer, students, administrators, stakeholders, parents of students, the community around the school, and the community around the campus. The whole human resources has certain characteristics that cannot be equated to each other.

Teachers, in general, already have qualified as a bachelor degree on certain subject. Most teachers already certified as a professional educator and got professional allowance. However, the activity of teaching in the classroom does not necessarily indicate an adequate level of professionalism. This happens because of the psychological situation of teachers is not stable; sometimes they are confidence, sometimes overreacting, and sometimes fluctuate.

Lecturer, generally already have qualification as a master degree in different scientific background. Even a small portion has been completed the doctoral, and most are studying 
doctoral. Job desk of a lecturer is: capable to conducting education and teaching in the classroom with 9 minimum of credits and 16 credits in a maximum. Then lecturer are also required to conduct research and develop the science independently or as a group that the results should published in scientific journals which accredited or not accredited, but publisher should have ISSN. Furthermore, a lecturer also required to perform community service activities individually and collectively. In addition, a lecturer also expected to have time to do additional activities in the form of participation in development activities, community and government.

Students, in general, are studying without doing the work. So they focused on subject, concepts and practical experience in schools. Coming home from school, they tend to play with their friends all the way to the residence. The homework did not do at home, but they did it in school, a few minutes before class start. Their distinctiveness lies in the spirit of going to school is very high and is followed by the pride of wearing the uniform, which sometimes they wear it until the afternoon even till night.

Students (of university), in general, have a very different character to the character of the students. A student has been able to manage the time during 24 hours to perform a variety of activities under control. The level of thinking and the ability to think hypothesis is more dominant on their typology of thinking. We can see it from the way they dress; the students tend to be able to choose and determine the color, shape and pattern of certain clothing suitable to their self and did not break the law of the university leaders. The ability of critical thinking and freedom to express idea become the character of students. Sometimes, when their thinking is stuck and ideas about social change, cultural, political and economic less getting a response from the government and certain communities, they held a peaceful action to brutal action through the demonstration activity gradually up until massive. The days of being a student of university seems to be the most beautiful and enjoyable time for most students.

Administrative staff, generally do not have the qualifications of bachelor degree, they mostly just graduated from high school. Some are already a bachelor degree, but the subject is often not linear with the field of work required. Workability of administration staff only imitated actions of the leader and the experience of doing the job. So their skill is limited. Because of that competence they need to be improved in a way participate in various training activities, workshops and seminars. Demands of administration to master the technology of communication is not negotiable, because it has become imperative that really must be mastered.

Stakeholders, in general, the government and the community around the school hopes that graduates of the institution is able to have the character such as discipline, creative, earnest and competitiveness for facing free market in the Asia-Pacific in 2020 that will come.

Parents, in general, are very concerned with the physical and psychological conditions of students, including socio-economic conditions of their children. Parents of students are so attentive to the future of their children with the loyalty that shown in giving money and also completing the needs such as shoes and uniforms for their children. Most parents are less 
concerned with the task of doing "homework" that has been given by the teacher. When the students achieve a good result of learning, the parents are satisfied, and then they say "Thank God, my son's grade. Thank God, my son got first rank. Thank God, my son had graduated". However, if the child is having problems such as failing a grade, do not get the top ten rankings, especially not passed, and then the parents will say: "who is the teacher, who is the classroom teacher, and who is headmaster".

Parents of student generally do not understand about the world of campus. In general, parents of students understand the world of college in two main phenomena, i.e., when the implementation of new student orientation period, and when held the event of the graduation ceremony. Parents of students in general do not understand grade point average (GPA), midterms and papers making tasks. Knowledge of parents is limited to know in which level his child studying in the college? When the exam session? And when their child graduate? These third questions become the favorite question of parents everywhere their child take lecture.

Communities around the school generally derived from middle and lower economic community groups with some variations that show groups of middle and upper class society. The existence of school gives benefit for the surrounding community. For example people who opened a little shop, street vendors, as well as the pitchman, they hope their shop sealable by students and teachers. Within certain limits, the community also benefited from the existence of the school and citizen of school, which is capable, became the inspiration for the local community to educate their children in school not far from where they live.

Communities around the campus generally are dominated by natives and migrants. The indigenous population in general comes from the middle class of economic, with some families that are in the middle class too. Certainly the migrant population is dominated by students who come from various regions around the campus are also currently studying on campus. Interaction between the indigenous population and migrants is actually the student, running relatively smoothly and peacefully. Remember that between both of them have a good cooperation and profitable. Students can rent houses of civil society, while the locals society get extra income from the rental cost and some other economic transactions in everyday life.

\subsection{Interaction of Educational Human Resources}

Among fellow of human resources in education there are direct interaction and symbolic interaction, particularly between: teachers and lecturers, teachers and students, teachers and administrators, lecturer and students, lecturer and students of college, lecturer and administrators, pupils and students, students and administrators, also students and administration.

Forms of interaction between teachers and lecturers are especially in terms of the implementation of Educational Practicum in Field Experience and Action Research Classroom. Educational Practicum in Field Experience implementation takes about 40 days. During the time of Educational Practicum in Field Experience some students of college was 
in school training to carry out a series of educational practicum activities that were tutored by teacher, according to the subject which have they learn, which has been designated by the principal. In the context of the implementation of this Educational Practicum in Field Experience every single group of participants of Educational Practicum in Field Experience were accompanied by one lecturer of Educational Practicum in Field Experience. In the process of guiding students of Educational Practicum in Field Experience occurs intensive interaction between teachers and lecturers until the completion of Educational Practicum in Field Experience program.

Forms of interaction between teachers and students mainly occurred on delivering of report books and also on study tour. Toward the event of delivering school report cards, teacher become very intensive on observing students' attitudes and behaviors in order to vote non-academic achievement and also the determine of class rank. Conversely, a student also requires interaction with teachers so that their existence is on rule in order to complete safe the educational programs. More intensive interaction of teachers and students is expected the score of report cards report cards became better. This is possible because the classroom teacher who is authorized to make negotiation with the subject teachers who give the score to the student "unfit" for students. The outcome of negotiations between the classroom teachers and subject teacher could give positive impact or bringing better value changes, could also have a negative impact in the sense that there is no change on students' grades.

Forms of interaction between teachers and students especially on Educational Practicum in Field Experience, and also when they promotion the college to student at third grade high school (Senior High School, Vocational high School and Islamic Senior High School). When Educational Practicum in Field Experience held, relationship between teachers and students are very intensive especially for teacher as tutors. Although only a tutor teacher that entitled to give an assessment of the students who participating in Educational Practicum in Field Experience, but spontaneously all the teachers definitely assess the performance of the students in Educational Practicum in Field Experience. Most teachers' asses the students by focusing on the appearance of students during school time, the assessment are also about the participants of Educational Practicum in Field Experience attitude toward teachers as well as to all other students. If students of Educational Practicum in Field Experience have bad attitude and bad appearance, then a student of Educational Practicum in Field Experience will get lack of support from classroom teachers. Finally, a number of student agenda can be hampered by the act of some teachers who gave a negative assessment of them.

Forms of interaction between teachers and administrators especially occurred in filling the identity of student in report cards and facing with troubled students so it is require a summons for the parents or need to do home visit activities to students who are in trouble. First grade teacher, especially teachers who were given additional duties as classroom teacher, must fill out personal data on students under his/her guidance. In order to easier on filling the identity, first grade teacher have to interact with employees of the administration. Because students' data stored in administration. Without the contribution of employee administration, it is very difficult for classroom teacher to fill the biodata of students successfully and smoothly. 
Forms of interaction between lecturer and students mainly occur during holding the seminar or training-based students who are held by the college education (such as quiz competitions and speech contest in three languages) and organized by the school (information about selection of majors and career development).

Forms of interaction between lecturer and students especially occur in the implementation of courses and extracurricular activities or organization inside and outside the campus. When learning activity in classroom, there was a high educational interaction between lecturer and students. The whole attitude, knowledge and skills of lecturers who appear in front of student become a consideration for students to take the attitude, knowledge and specific skills that lecturer has as their idol. For lecturers who did not become an idol of students, it probably the meaning of interaction between lecturer and students is symbolic only, not to reach internalization and acculturation level. For favorite lecturers it would become a point how to act, thought and a certain attitude to various issues that encountered in his life.

Forms of interaction between lecturer and administration especially occur in terms of practical implementation of a subject and the distribution of tasks mail or other important papers. Implementation of subject practicum occurs at the end of each semester. At the moment of these activities occur the intensive interaction between lecturer and administration. Because the letter of assignment and a decree of activities committee usually affected by the administration of campus. A lecturer will not be conducting practicum if he/she is not listed by name in the letter of assignment that signed by the dean or by the rector. With making the establishment of good cooperation between lecturers and administrative staff, then a series of intra-curricular campus activities can run more smoothly.

Forms of interaction between students of high school and students of college, especially occurs during extracurricular activities that carried out in a certain environment and extracurricular school conducted by the college education. Extracurricular activities held in school sometimes involving alumni from the school. Instead extracurricular activities on campus the college education often involve high school students who come from schools that the college education students come.

Forms of interaction between students and the administration particularly occur in selecting subject process at senior high school level or division level at elementary and junior high school classes. The process of selecting majors at the senior high school level involves the role of corporate governance, especially in collecting data of parents. It includes on making and distributing questionnaires about the opinions of parents regarding the selection of majors. It is often occur that parent willingness and achievement of student are not mutually support each other. In determining alternative majors, parents willing to make their child choose science major, while learning achievement of students tend to be more suitable for social major. This is where the role of administration in "combining" the achievement of student with willingness of their parents.

Forms of interaction between students and administrators especially occur in terms of class division, the classifying the group of Community Service Program, and the distribution of the graduation gown. Class divisions and the classifying the group of Community Service 
Program are usually based on the alphabetical order of the names of students. As a result, student name beginning with the letter A, will occupy the classes A, followed by name of student with alphabet $B$, and so on, so that the student name that begins with the alphabet $Z$, inevitably, have to occupy the last class or the last group of the allocation of a class or group which exists. In addition, when distributing graduation gown, calling the names of students is also based on the order of attendance, which in alphabetical order again. In this way, there is an impression that the student names beginning with the letter " $A$ " will always come in different way at campus. Instead, the names of students beginning with the letter " $Z$ ", will always receive the last service. The same thing happened with the current division of the group Community Service Program , student name beginning with "A" get Community Service Program location relatively closer and more comfortable than a student whose name begins with the letter " $Z$ ".

\subsection{Conflict of Educational HR}

Among HR education, whether consciously or not, the conflict symbolic prolonged between: teachers and lecturers, teachers and students, teachers and students of college, teachers and administrators, lecturer and students, lecturer and students of college, lecturer and administrators, high school student and students of college, students and administrators, students of college and administration.

Conflict between teachers and lecturers especially occur in terms of differences incentive allowance, the workload, the use of uniforms and participation in the ceremony. During this incentive allowance is paid based on the teaching profession of personnel. All the teachers of the class II get the amount of the incentive allowance of the same profession throughout Indonesia; it is about 175 thousand rupiah. All teachers from class III get the incentive allowance about 275 thousand rupiah. All the teachers of the class IV earn an incentive allowance about 375 thousand rupiah. While, the professional allowance of lecturer is based on their position and their grade. All lecturers as Educative Assistant Expert getting a professional allowance about 500 thousand rupiah per month. All lecturers as Lectureship get professional allowance about 700 thousand rupiah per month. All lecturers who held the rank of Associate Professor educative get an incentive about 900 thousand rupiah per month. All lecturers have educative rank professor or professor, get professional allowance about 1.300 .000 , - rupiahs per month.

The workload of teachers is 24 hours per week which cause a teacher should always be in school at least four days a week (especially secondary school teachers). But in general, school leaders requires all teachers to come to school every day for six days (especially primary school teachers) and sometimes leadership requires all teachers to come to school at least five days a week (especially the leadership of junior high school). While the workload of lecturer is about 12 credits and a maximum of 16 credits in a semester, if it calculated according to the daily, then a lecturer must be at work for two days a week (especially the lecturer who lived far from the campus). Lecturers who lived relatively close to the campus attempted to come to campus with minimum of three working days. Lecturers who received extra duty as a leader on campus are required to work with minimum five days in one semester. 
The conflict between teachers and students especially occur in the distribution of daily test results, distribution of temporary report cards, and the determination of the majors in high school. Sometime after the subject teachers share the results of daily tests to students, most students were surprised about their learning results. The shock was an upsurge of covert conflict between the subject teachers with the students who are not get maximum score in daily test. On conditions of hidden conflict above, the relationship between teachers and students still take place in the classroom and outside the classroom, through the distribution of temporary report cards agenda arrived.

When the distribution of temporary report cards, the score is taken from the results of the midterm quiz, hidden conflict between teachers and students reappeared. This time it comes from serving original score and makes students surprised. Most of students got low test scores. As a result of that problem it emerged the hatred prospective from students to teachers who give temporary report cards not optimal. Indeed, perhaps, those temporary score becomes smaller when compared to the original score of the results of general tests that have got the "intake" score based on the consideration of attitudes, knowledge and skills of students who could be known by the subject teachers.

Hidden conflict between teachers and students will reach its peak when the announcement of the distribution class at second-grade students of Senior High School, Vocational high School and Islamic Senior High School. At that time, between teachers, students and parents tend to have the difference "tastes". Students want to get the social program, but parents want his child to take science program. Sometimes teachers are given additional duties as classroom teacher, make decisions for determining the majors that do not fit the taste of students or parents.

The conflict between teachers and students of college especially occur in terms of the implementation of extracurricular activities involving alumni and organizational activities that involve junior and senior high school students. It is often extracurricular agenda collide with a schedule of teaching and learning in the classroom. When teachers teach in the classroom, and most of students attend extracurricular activities, which are sometimes fostered by alumni, there was a prolonged conflict between subject teachers and students who become the leader of extracurricular activities. Students who have good learning achievement usually have less achievement in extracurricular activities. Instead, students who have a good performance in the field of extra-curricular, academic achievement is often not even good. This condition make the level of conflict sharpen between of teachers and students who become leader in extracurricular activities at school.

Conflict between teachers and administrators especially occur in terms of the distribution of the incentives or honoraria of activities. The number of extracurricular activities at a school has an impact on the amount of incentive or honorarium activities that will be accepted by a tutor or teacher. At the same time, the "extra" activities which do by administrators become more limited, because of the splendor of extracurricular activities. It makes honorarium extracurricular activities for personnel administration relatively smaller compare with honorarium received by a tutor. A wise headmaster should be involve personnel 
administration actively in extra-curricular activities of the school with additional duties as a tutor and as a teacher coaches a certain extracurricular activities.

The conflict between lecturer and students especially occur on delivering a promotion of college before high school students in grade three. The universities tend to steer students to study in certain majors in college which concerned on finding and determining a primary consideration majors or courses that have been accredited by the National Accreditation Board of Higher Education. More specific, the college is represented by a lecturer who has been appointed tend to steer students to the department which have accreditation A or B. Whereas the accreditation status (accreditation of A or B) have little effect on the interest of students of high school graduates to continue their studies on certain courses they have learn its characteristics or profile. High school graduates tend to choose a program of study that is already popular or widely known by the people from various social strata. For example, accounting courses at the faculty of economics, mathematical studies program at the faculty of Mathematics and Engineering Department at the Faculty of Engineering, Built Environment and Regional Development as well as the program of study Electrical Engineering at the Faculty of Engineering is the most popular courses in student view of high school graduates.

The conflict between lecturer and students especially occur in terms of providing a structured tasks and procedures following the lecture. Lecturer is often providing structured assignments to students which are quite hard and must be completed within a week. Considering the limitations of the students, in the case of ownership of laptop or internet service utilization program especially Google, provision of the task often burdensome students. They had joked that the college still easy. But the burden is structured task. In addition, there are still some lecturers who make the procedure to follow the lecture with complicated requisite for the students, but they could not resist. For example a lecturer who requires that when lecturers have entered the classroom, the students were barred from college, for any reason. There is also a lecturer who makes the rules for every task of making paper must be immediately collected and corrected in detail, and the results should be corrected as desired by the professor. So the expected tasks more qualified.

The conflict between lecturer and administration especially occur in terms on giving fees or incentive of activities that nominal is unclear. In training, seminars or other activities they often have conflicts between lecturers and employees of the administration. The beginning of conflict usually comes from the division of fees or incentive campus activity is unclear. Lecturer feels that their fee and incentive fees less than the amount that should have been, but at the same time, employee administration felt it had helped the professor to impose direct taxes on income earned by the professor. The core source of conflict is ignorance lecturer on tax cuts automatically by the administration, which is equipped with a lack of information about the auto tax cuts. The result was a prolonged cold conflict between lecturers and administrative staff.

Conflicts between students in high school and students in college especially occur in the sport championship that involves students in college as the committee and extracurricular activities 
on campus involving students as participants.

Conflicts between students and administrators especially occur in terms of monitoring implementation of the current general tests or final exam of the semester and the payment of SPP, which have to be paid. At the time of general tests held, the interaction of students with administrative staff tends to be tension. This happens because in the moments of general tests took place, students require supervision situation comfortable, but the style of supervision performed by administrative staff tend to be rigid and strict. As a result, many students lose sympathetic to the behavior of the administration in charge of the room. Instead the employees also keep a sense of annoyance and disturbed over the behavior of students who supervises general tests.

Conflicts between students and administrators, especially in terms of the implementation process of research students taking research sites in schools and the implementation of the midterm and final exams in college who commissioned personnel administration as supervisor. Students tend to have freedom expression of cognitive, affective, and psychomotor, forced to confront the bureaucratic employee figure, stiff and tense.

\subsection{Integration of Educational HR}

Human resources in the field of education, when doing an activity that is nuanced education an integration of continuous between: teachers and lecturers, teachers and students, teachers and students, teachers and administrators, lecturer and students, lecturer and students, lecturer and administrators, students and students, students and administrators, students and administration.

Integration of teachers and lecturers especially occur in terms of the implementation Educational Practicum in Field Experience and classroom action research. During the implementation of Field Education Program Introduction, the integration of teaching profession and lecturers were running intensive, progressive and creative. The existence of a central teacher tutor holds the key for the success of Educational Practicum in Field Experience in school. Considering that the assessment of objective score given by the teacher to the ability to teach of students Educational Practicum in Field Experience can be raised. In this case, the position of lecturer is more than advisors and mentors for the implementation Educational Practicum in Field Experience. Indivisibility perceptions, attitudes and educational skills among teachers and lecturers are felt at the time of Educational Practicum in Field Experience. Teachers have a wealth of experience about classroom management and teaching methodology. While the professor has insight broader knowledge about the substantive material taught during the discussion of the primary in the learning process as well as theoretical and philosophical meaning of certain educational background for teacher professional development.

Integration of teachers and students especially occur in terms of the learning process in the classroom and the implementation of the study tour. Integration of teachers and students, especially in terms of the implementation of the seminar held by students and teachers involve certain subjects. Integration of teachers and administrators especially occur in terms 
of the implementation of the picket and sharing teaching schedule. Integration of lecturer and students especially occur in terms of publishing a new book and implementation of tutoring and career guidance of students. Integration of lecturer and students especially occur in terms of the implementation of lectures in the classroom and outside the classroom. Integration of lecturer and administrators especially occur in terms of the distribution of handbooks and the documents, official travel document. The integration of high school students and students of college especially occur in terms of the implementation of mentoring certain subjects involving students as tutors or facilitators power. Integration of students and administrators, especially in terms of payment of education financing and payment of other costs that nominal still affordable.

The integration of student and corporate governance, especially in the case of granting operating licenses of extracurricular activities and also permission of the final project in the form of thesis. Extracurricular activities on the college education campus must obtain permission from the head of the administration of the faculty. When the extracurricular activity has received the operating license, the campus community will receive the impact that all campus facilities can be utilized.

\subsection{Collaboration of Educational HR}

In a certain stage, actually educational HR do the limited collaboration on achieving the specific goals that they have agreed, such as the socialization of the new curriculum (Curriculum 2013), implementation of the concept of school-based management, the implementation of the concept of Curriculum Education Unit, also the implementation on using school operations donation. Educational HR often collaborate among others: teachers and lecturers, teachers and high school students, teachers and students of college, teachers and administrators, lecturer and high school students, lecturer and students of college, lecturer and administrators, high school student and students of college, high school students and administrators, student of college and administration.

Collaboration between teachers and lecturers especially occur in terms of the implementation of field work experience programs and activities of classroom action research. Collaboration between teachers and students especially occur in terms of implementation of extra-curricular activities and study tour. Collaboration of teachers and students especially occur in terms of the implementation of the Education Field Experience Program. Collaboration teachers and administrators especially occur in terms of data collection of new student and school graduation. Collaboration between faculty and students especially occur in terms of coaching and developing their talents, interests and student achievement. Collaboration of lecturer and students especially occur in terms of the implementation of lectures and filed practicum. Collaboration of lecturer and administrators especially occur in terms of the preparation for the lecture and the procurement of student attendance. Collaboration between high school students and students of college especially occur in terms of tutoring and mentoring activities of religious. Collaboration students and administrators, student collaboration and corporate governance, especially in terms of issuing research permission and certificates as an active student. 


\section{Conclusion}

Based on the results of the literature review and the discussion above, it can be concluded as follows: First, Education Human Resources consists of: teachers, high school students, students of college, administrators, stakeholders, parents of students, the community around the school, and the community around campus, with particular characteristics; Second, Inter fellow of field Human Resources of education is an interaction of direct and symbolic interaction that obvious, especially between: teachers and lecturers, teachers and high school students, teachers and students of college, teachers and administrators, lecturer and high school students, lecturer and students of college, lecturer and administration, high school student and students of college, high school students and administrators, and students of college and administration; Third, among educational Human Resources the conflict symbolic prolonged between teachers and lecturers, teachers and high school students, teachers and students of college, teachers and administrators, lecturer and high school students, lecturer and students of college, lecturer and administration, high school student and students of college, high school students and administrators, and students of college and administration: Fourth, educational Human Resources, when doing an activity of education nuanced there is integration that occur continuously between teachers and lecturers, teachers and high school students, teachers and students of college, teachers and administrators, lecturer and high school students, lecturer and students of college, lecturer and administration, high school student and students of college, high school students and administrators, and students of college and administration; and Fifth, in a certain stage, actually educational Human Resources establish limited collaboration on achieving the specific goals that they have agreed, such as the socialization of the new curriculum (Curriculum 2013).

Connected to conclusions, the authors propose the following suggestions: First, the lecturer should be aware of its position as the last process of forming character of students towards the better future, more equitable, and more fun; Second, teachers should be aware of its position as the foundation on making the character of students and the elaborate academic values in school; and Third, high school students and students of college are expected to have a tough motivation in establishing their character and also developing a number of interests and talents that they have.

\section{References}

Anonymous. (2003). Law on National Educational System of Indonesia Year 2003.

Anonymous. (2005). Government Regulation No. 19 on National Education Standards of Indonesia Year 2005.

Fattah, N. (2012). Analysis of Educational Policy. Bandung: Remaja Rosdakarya.

Mulyasana, D. (2011). Quality and Competitive Education. Bandung: Remaja Rosdakarya.

Onisimus, A. (2011). Educational Management in the Era of Regional Autonomy. Bandung: Alfabeta.

Sagala, S. (2007). Strategic Management in Educational Quality Improvement. Bandung: 
Alfabeta.

Saud, U. S. (2009). Professional Development of Teacher. Bandung: Alfabeta.

Tilaar. (2000). New Paradigm of National Education. Jakarta: Rineka Cipta.

\section{Copyright Disclaimer}

Copyright for this article is retained by the author(s), with first publication rights granted to the journal.

This is an open-access article distributed under the terms and conditions of the Creative Commons Attribution license (http://creativecommons.org/licenses/by/3.0/). 